Check for updates

The BMJ

fgodlee@bmi.com Follow Fiona on Twitter @fgodlee

Cite this as: BMJ 2021;373:n1540 http://dx.doi.org/10.1136/bmj.n1540 Published: 17 June 2021

\title{
Covid-19: Failures of leadership, national and global
}

\section{Fiona Godlee editor in chief}

How well prepared were countries for this pandemic? Back in October 2019 the US and the UK were top of the world rankings as scored by the Global Health Security Index. The Epidemic Preparedness Index also gave them a thumbs up. And yet both countries are among the world's worst performing, whether judged by numbers of deaths from covid-19 or economic outcomes. How could these indexes have got it so wrong?

Although the GHSI warned that, overall, the world was not well prepared, Fran Baum and colleagues concluded that a range of assumptions led to it overestimating the preparedness of richer nations while overlooking key social, political, and geographic weaknesses that the pandemic has so cruelly exposed (doi:10.1136/bmj.n91). ${ }^{1}$ These included having wider socioeconomic inequality, less social solidarity, and weaker public health systems that rely on private companies (reference the UK's privatised track and trace debacle, masquerading under the NHS logo). "The crucial lesson from the covid-19 pandemic is that an effective response ... requires a society that is fair and offers all its citizens and residents social and economic security," Baum and colleagues concluded.

Good governance and political leadership must also be factored in. Corrupt and opaque procurement has tainted the UK government's response, to which Stephen Reicher and colleagues add other charges: namely, this government's damaging tendencies towards popularism, paternalism, UK national exceptionalism, and "anti-welfarism" (https://blogs.bmj.com/bmj/2021/06/og/whygroupthink-detracts-from-an-explanation-of-the-organisational-failures-of-the-uk-pandemic-response). ${ }^{2}$

Both the US and the UK might have made up for their failings at home by stepping up on global leadership. Sadly, there's little evidence of this. Boris Johnson's promise to "vaccinate the world" has already fallen short, with the G7 nations committing to only one billion vaccines in the coming year, well short of the 11 billion needed (doi:10.1136/bmj.n1520), ${ }^{3}$ effectively renouncing their role as global health leaders in what Kent Buse and Katri Bertram call a "historic missed opportunity"

(https://blogs.bmj.com/bmj/2021/06/13/g7-leadersmade-few-concrete-strong-or-deep-health-relatedcommitments-at-carbis-bay). ${ }^{4}$ Waiving intellectual property rights on the vaccines seems a vital next step, but commitments from several countries have yet to be enacted (doi:10.1136/bmj.n1344). ${ }^{5}$

Meanwhile the pressure on healthcare staff continues to take its toll. Relying on individual resilience is clearly not the answer (https://blogs.bmj.com/bmj/2021/06/11/davidwrigley-dont-call-us-resilient). ${ }^{6}$ Staff face the mammoth task of dealing with the covid backlog and the emotional and practical challenges of growing waiting lists, which are especially dire in Northern Ireland (doi:10.1136/bmj.n1479). ${ }^{7}$ A new approach to tackling surgical waiting lists is welcome but must take account of training needs if the workforce is to be safely expanded (doi:10.1136/bmj.n1499). ${ }^{8}$

The delta variant's role in the latest increase in cases and hospital admissions remains unclear (doi:10.1136/bmj.n1513), ${ }^{9}$ but there is little doubt in the minds of Deepti Gurdasani and colleagues that spread in schools is a cause for grave concern and requires immediate action (https://blogs.bmj.com/bmj/2021/06/11/covid-19and-the-delta-variant-we-need-an-urgent-focus-onmitigations-in-schools). ${ }^{10}$ Given these challenges and uncertainties, the UK government has made the right decision in delaying further relaxation of restrictions. We will have to wait and see whether other more difficult lessons can be learnt.

Baum F, Freeman T, Musolino C, etal. Explaining covid-19 performance:
what factors might predict national responses?BMJ2021;372:n91.
doi: 10.1136/bmj.n91 pmid: 33509924
Reicher S. Why “groupthink” detracts from an explanation of the
organisational failures of the UK pandemic response. BMJ Opinion. 9 Jun
2021. https://blogs.bmj.com/bmj/2021/06/09/why-groupthink-detracts-
from-an-explanation-of-the-organisational-failures-of-the-uk-pandemic-
response.
Wise J. Covid-19: G7 vaccine promises fail to meet scale of challenge, say
critics. BMJ2021;373:n1520doi: 10.1136/bmj.n1520.
Buse K, Bertram K. G7 leaders made few concrete, strong, or deep
health-related commitments at Carbis Bay. BMJ Opinion. 13 Jun 2021.
https://blogs.bmj.com/bmj/2021/06/13/g7-leaders-made-few-concrete-
strong-or-deep-health-related-commitments-at-carbis-bay.
Krishtel P, Malpani R. Suspend intellectual property rights for covid-19
vaccines. BMJ2021;373:n1344. doi: 10.1136/bmj.n1344 pmid: 34049897
Wrigley D. Don't call us resilient. BMJ Opinion. 11 Jun 2021.
https://blogs.bmj.com/bmj/2021/06/11/david-wrigley-dont-call-us-resilient.
Smyth L. The seven year wait: Northern Ireland’s disintegrating secondary
care services. BMJ2021;373:n1479.
McCrossan R, Munro C. A new deal for surgery: but what does it really
mean?BMJ2021;373:n1499doi: 10.1136/bmj.n1499.
Mahase E. Delta variant: What is happening with transmission, hospital
admissions, and restrictions?BMJ2021;373:n1513doi: 10.1136/bmj.n1513.
Gurdasani D, Ziauddeen H, Reicher S, McKee M. Covid-19 and the delta
variant-we need an urgent focus on mitigations in schools. BMJ Opinion.
11Jun 2021. https://blogs.bmj.com/bmj/2021/06/11/covid-19-and-the-delta-
variant-we-need-an-urgent-focus-on-mitigations-in-schools.

This article is made freely available for use in accordance with BMJ's website terms and conditions for the duration of the covid-19 pandemic or until otherwise determined by BMJ. You may use, download and print the article for any lawful, non-commercial purpose (including text and data mining) provided that all copyright notices and trade marks are retained. 